\title{
Correction to: Design and modeling of a novel high sensitive MEMS piezoelectric vector hydrophone
}

\author{
Bahram Azizollah Ganji ${ }^{1}$ (D) Mojtaba Shams Nateri ${ }^{1} \cdot$ Morteza Dardel $^{2}$
}

Published online: 28 February 2018

(C) Springer-Verlag GmbH Germany, part of Springer Nature 2018

\section{Correction to: Microsystem Technologies}

https://doi.org/10.1007/s00542-018-3770-0

In the original article, one of the co-author's (Morteza Dardel) family name has been published incorrectly. The correct family name should be Dardel.The original article has been corrected.

The original article can be found online at https:// doi.org/10.1007/s00542-018-3770-0.

Bahram Azizollah Ganji

baganji@nit.ac.ir; bahramganji23@gmail.com

Mojtaba Shams Nateri

mojtaba_shams_n@yahoo.com

Morteza Dardel

dardel@nit.ac.ir

1 Department of Electrical and Computer Engineering, Babol Noshirvani University of Technology, Babol, Iran

2 Department of Mechanical Engineering, Babol Noshirvani University of Technology, Babol, Iran 